\title{
Chromatographic Methods for Evaluation of the Amino Acid and Fatty Acid Compositions Related with Pork Quality
}

\author{
Nadezhda V. Bogolyubova, Sergei Yu. Zaitsev * \\ L.K. Ernst Federal Science Center for Animal Husbandry, Dubrovitsy 60, Podolsk Municipal District, \\ 142132 Moscow, Russia; 652202@mail.ru (N.V.B.); s.y.zaitsev@mail.ru (S.Yu.Z.). \\ * Correspondence: s.y.zaitsev@mail.ru (S.Yu.Z.); Tel.: +7-4967-651363
}

\begin{abstract}
The increasing demand for high-quality livestock products dictates to develop approaches to assessing the composition of the fatty acids (CFAs) and amino acids (CAAs) in animal tissues. The review considers the following issues: chromatographic methods for the determination of CAAs and CFAs of pig tissues; factors influencing the CAAs and CFAs of pig tissues; methods of regulating CAAs and CFAs of pork using nutritional factors; the effect of CAAs and CFAs on formation of meat properties. The main methods for determining CAAs or CFAs are the ion-exchange or gas chromatography, respectively. The total FA amount and individual FAs have significant effects on the tenderness, taste, color and juiciness of pork meat (due to the different melting points of particular fatty acids, formation of lipid oxidation products during cooking, etc.). Muscle proteins of pigs with regulated fatness differ also in CAAs (decreasing by increase in "pork fat" and decrease in the protein's amount. The significance of this review is also determined by high popularity of pork in Russia and in a number of other countries of the world.
\end{abstract}

Keywords: chromatography, amino acids, fatty acids, pork analysis, adipose tissue, muscle tissue, nutritional factors.

\section{Content:}

1. Introduction

2. Chromatographic methods of analysis of the fatty acids and amino acids in animal meat

3. The influence of fatty acid and amino acid composition of pig tissues on the formation of physical-chemical properties of meat

4. The influence of the most important factors on contents of pork's fatty acids and amino acids

5. Conclusions

AAs - amino acids,

Abbreviations:

ATP - adenosine triphosphate,

BACs - biologically active components,

BJBP - Berkshire $\times$ JBP,

DBJBP - Duroc $\times$ Berkshire $\times$ JBP,

DLJBP - Duroc $\times$ Landrace $\times$ JBP,

DIAAS - digestible indispensable amino acid score

EAAs - "essential" amino acids,

GPC - gas permeable chromatography,

HPLC - high permeable liquid chromatography,

IMF - intramuscular fat,

JBP - Jiaxing Black Pig,

LC - liquid chromatography,

LM - Longissimus muscle,

MUFAs - monounsaturated fatty acids,

PMQA - pig meat quality assessment, 
NEAAs - "non-essential" amino acids,

PUFAs - polyunsaturated fatty acids,

SFAs - saturated fatty acids,

UFAs - unsaturated fatty acids,

WHC - water holding capacity.

\section{Introduction}

Meat (for human consumption) is a source of valuable proteins (including peptides and amino acids), fat (including triacylglycerols and other lipids), numerous mineral and extractive substances, vitamins, the presence of which is necessary for the nutrition and normal functioning of all mammals [1-5]. There are also L-carnitine, coenzyme $\mathrm{Q}_{10}$, carnosine, taurine, creatine, glutathione, lipoic acid, conjugated linoleic acid, Omega-3 and Omega-6 polyunsaturated fatty acids (PUFAs), etc., among the known biologically active components (BACs) of meat, that can promote human health and act as the supplements in a meat diet [1-5]. The antioxidant capacity of these BACs in meat allows inhibiting oxidative processes in the human body, which can cause the progression of various diseases [6]. Some meat BACs exhibit an antihypertensive effect, preventing cardiovascular diseases, etc. [3-6].

The biological value of meat proteins largely depends on the ratio of "essential" amino acids (EAAs) in their samples (lysine, methionine, tryptophan, phenylalanine, leucine, isoleucine, threonine, valine, arginine and histidine), which cannot be synthesized by humans or animals, i.e. must be supplied by diet [3-6]. At average, an adult should receive about 1.0-1.2 g of protein per $1 \mathrm{~kg}$ of body weight with food during the day (depending on physical activity), and at least $30 \%$ of a person's daily protein diet should be completed by proteins containing all essential amino acids [4,5]. Tryptophan, lysine, methionine are especially deficient in this sense [3-6]. All other (so called "non-essential or replaceable") amino acids (NEAAs) are also valuable for the human body, i.e. they perform various functions and play same important roles, as well as EAAs. For example, NEAA like glutamic acid is the most important acid that supports the neurotransmission, respiration of brain cells, etc. [7]. There is a strong evidence that some of the NEAAs play an important regulatory role in gene expression, cell signaling, nutrient metabolism, and even in animal reproduction [8].

On the other hand, a novel concept of "functional" amino acids has appeared recently, pointed the AAs whose functions are not limited to protein synthesis [8,9]. This concept is proposed to highlight exactly those amino acids (both, NEAAs and EAAs) that regulate key metabolic processes in the body, contribute to improving health, safety, growth, development, reproduction function, productivity, etc. [8,9]. For example, arginine, serine, tyrosine, cysteine, and glutamic acid are referred to the "functional" amino acids with multiple physiological functions [6,9]. In this sense, the authors of this review proposed to mention such AAs as "multifunctional" instead of simply "functional", that would better reflected their numerous valuable properties.

Meat is also considered to be the main source of important unsaturated fatty acids (UFAs) in the human diet [1-5]. For example, among the three essential polyunsaturated fatty acids, arachidonic acid has the highest biological activity (2-3 times higher as those for linoleic or linolenic acids). Its absence or deficiency in the human diet delays physiological development [10]. In the human diet, nutritionists pay attention to the ratio of polyunsaturated (PUFA) to saturated (SFA) fatty acids, which should tend to a level above 0.4 , but such analysis is rare for animals [5]. Modern study in human diet is paying a great attention to the content of particular PUFA, as well as the balance between $\omega-3$ PUFA (18: 3) and $\omega-6$ PUFA (18: 2 ) in the nutrition BACs [11].

Pork is a valuable food product for people, which has good nutritional and taste qualities. It is important that pork retains the valuable properties during any processing and conservation (production of sausages, smoked meats, etc.). In terms of meat popularity in Russia, pork is not inferior to beef and lamb, but a lit bit lower than poultry. Pork contains less than other types of meat, such proteins as collagen and elastin (with less EAA as other essential proteins) [12]. The quality of pork, including its chemical and technological properties, largely depends both, on the amino acid composition of muscle tissue and the ratio of various fatty acids in adipose. Improving the quality of meat and "relative" products (obtained from it) is an urgent task facing agricultural producers and 
processors. That is why regulation of the composition of amino acids and lipids in pork (as well as in the meat of other productive animals) is an important problem for scientists and practitioners in the field of animal husbandry both in Russia and in the world.

The purpose of this review is to summarize the results of numerous domestic and foreign studies in the field of pork biochemistry, in particular, the fatty acid and amino acid compositions and their influence on the formation of the pork properties and quality; description of various factors, including the diet of animals; the content of these nutrients in the tissues of pigs and methods for their determination.

\section{Methods for determination of amino acids and fatty acid in animal meat}

The following HPLC methods are known for analyzing food products [13, 14]: ultra-HPLC, "hydrophilic" chromatography [15], two-dimensional and multidimensional HPLC methods [16 =78], chiral chromatography [17], express chromatography [18, 19], capillary HPLC [20], nano-HPLC [21], micellar HPLC [22], HPLC on monolithic columns [23], HPLC on surface porous sorbents [24], immunochromatographic methods [25], green chromatography [26], high-temperature HPLC [27] The most common methods for the determination of amino acids and fatty acids are reversed-phase, cation-exchange HPLC and gas chromatography, respectively (Fig. 1).

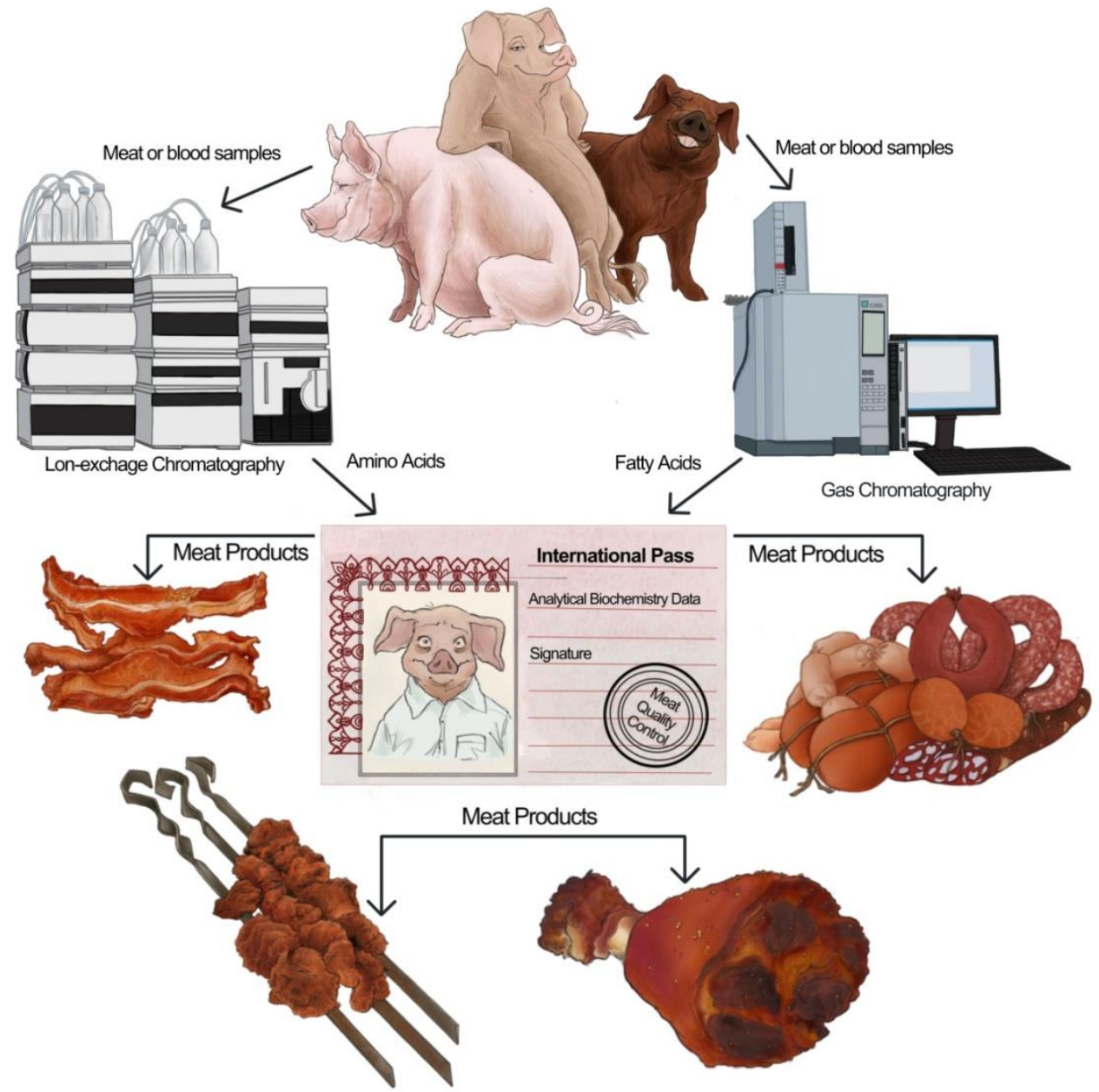

Figure 1. Schematic drawing of the chromatography methods for analyzing AA and FA content in pork blood and meat for evaluation of the food product quality.

Free amino acids are isolated from samples by extraction. Acid hydrolysis with $6 \mathrm{M}$ hydrochloric acid is most often used for protein degradation [28].The absence of chromophore groups in most amino acid molecules requires a derivatization step. Various reagents have been proposed for pre- and post-column derivatization [29, 30].

Dudkina N.N. and co-authors (2017) [31] proposed and tested a method of reversed-phase liquid chromatography (with spectrophotometric detection) for AA analysis in pig's tissues and 
organs. Sample preparation included preliminary hydrolysis of proteins with $6 \mathrm{M} / \mathrm{L}$ solution of hydrochloric acid. The hydrolysates were subjected to precolumn derivatization with phenyl isothiocyanate for spectrophotometric recording on a reversed-phase column in a gradient mode. Amino acids were identified with respect to a mixture of standard samples that passed all stages of analysis [31].

An improvement of HPLC technology and its wide practical application solves the problems of separation and quantitative determination of very small amounts $(10 \mathrm{mg} / \mathrm{kg}$ and below) of determined components in complex objects [32]. The authors proposed a method for determining the most important amino acids in complex matrices of biological origin, which include meat samples, by reverse phase HPLC with UV-detection using acid hydrolysis and modification of amino acids with a solution of phenyl isothiocyanate in isopropyl alcohol to obtain phenylthiohydantoins. The authors established the $\mathrm{pH}$ influence of the mobile phase on the separation factors of amino acids, proposed to optimize the conditions for acid hydrolysis of samples by performing a sample preparation procedure, including acid hydrolysis of samples and modification of amino acids with a solution of phenyl isothiocyanate. A hydrolysis and other technique have been described previously and the resulting AA solutions were subjected to chromatographic analysis [13-15, 31-33].

The methods for determining the amino acid and fatty acid composition of pork according to different authors are summarized in the Table 1. Analyzing the data in the table, we can conclude that the main method for determining the content of amino acids in the tissues of pigs is the method of ion exchange chromatography, fatty acids - the method of gas chromatography.

Table 1. Methods of the analysis of amino acids and fatty acid content in pork.

\begin{tabular}{|c|c|c|c|c|}
\hline № & Objects, heads, genotype, etc. & Goals & Methods & Refs. \\
\hline 1 & $\begin{array}{l}\text { AA in pork meat ( } 10 \text { meat samples, } \\
\text { used in the production of sausages } \\
\text { at the enterprises of the Tambov and } \\
\text { Lipetsk regions). }\end{array}$ & $\begin{array}{l}\text { Assessment of the quality of } \\
\text { meat obtained from various } \\
\text { (domestic and foreign) } \\
\text { suppliers. }\end{array}$ & $\begin{array}{c}\text { Ion-exchange } \\
\text { chromatography (analyzer } \\
\text { "AAA - 400, Ingos"). }\end{array}$ & $\begin{array}{c}\text { Gubanov } \\
\text {, D.G. } \\
2011 .\end{array}$ \\
\hline$\underline{2}$ & $\begin{array}{l}\text { AA in pork meat (a few dozens of } \\
\text { meat samples). }\end{array}$ & $\begin{array}{l}\text { Assessment of the meat quality } \\
\text { at storage. }\end{array}$ & $\begin{array}{l}\text { HPLC, derivatization with } \\
\text { orthophthalic aldehyde. }\end{array}$ & $\begin{array}{c}\text { Knyazev } \\
\text { a, A.S. } \\
2017 .\end{array}$ \\
\hline 3 & $\begin{array}{l}\text { Content of free AA and FA in } \\
\text { muscle tissue of rearing and } \\
\text { fattening pigs ( } 60 \text { animals, Duroc x } \\
\text { Large white } x \text { Landrace). }\end{array}$ & $\begin{array}{l}\text { Assessment of the meat quality } \\
\text { because of a change in the } \\
\text { composition of the diet (addition } \\
\text { of L-arginine and glutamic acid } \\
\text { to the diet). }\end{array}$ & $\begin{array}{l}\text { AA - HPLC (L-8800; Hitachi); } \\
\text { FA - GPC (Agilent 6890N) }\end{array}$ & $\begin{array}{l}\text { Guo, Q.et } \\
\text { al., } 2019 .\end{array}$ \\
\hline 4 & $\begin{array}{l}\text { Free AA and FA content in pig meat } \\
\text { products (dry pork fillets in vacuum } \\
\text { packing). }\end{array}$ & $\begin{array}{l}\text { Assessment of the meat quality } \\
\text { because of a change in the } \\
\text { mixture of the probiotics. }\end{array}$ & $\begin{array}{c}\text { Ion-exchange } \\
\text { chromatography (analyzer } \\
\text { "AAA - 400, Ingos"). }\end{array}$ & $\begin{array}{l}\text { Neffe-Sk } \\
\text { ocińska, } \\
\text { K. et al., } \\
2016 .\end{array}$ \\
\hline 5 & $\begin{array}{l}\text { AA and FA content in pig meat, } 47 \\
\text { boletus and } 47 \text { gilts, divided into } \\
\text { groups: CChS }(\mathrm{n}=22), \mathrm{BTSChS}(\mathrm{n}= \\
\text { 18), DBChS }(\mathrm{n}=18), \mathrm{DLCChS}(\mathrm{n}= \\
18) \text {, Berkshire }(\mathrm{n}=18) /\end{array}$ & $\begin{array}{l}\text { Assessment of the meat quality } \\
\text { of various animal genotypes. }\end{array}$ & $\begin{array}{l}\text { FA - GPC (Agilent 6820; } \\
\text { Agilent Technologies); } \\
\text { AA - Ion-exchange } \\
\text { chromatography (S-433D } \\
\text { Sykam Automatic Amino } \\
\text { Acid Analyzer). }\end{array}$ & $\begin{array}{l}\text { Zhang, } \\
\text { W. et.al. } \\
2019 .\end{array}$ \\
\hline 6 & AA and FA content in pig meat $(40$ & Assessment of the meat quality & FA - GPC (Agilent 6820, & Jiang, Y. \\
\hline
\end{tabular}




\begin{tabular}{|c|c|c|c|c|}
\hline & $\begin{array}{l}\text { castrated boars are divided into } \\
\text { breed groups: aboriginal Dahe and } \\
\text { Davout crossbreeds). }\end{array}$ & of various animal genotypes. & $\begin{array}{l}\text { Agilent Technologies) using } \\
\text { a capillary column } \\
\text { (HP-Innowax, Agilent, } \\
\text { length } 30 \mathrm{~cm}, \mathrm{D}=0.32 \mathrm{~mm} \\
\text { and film thickness } 0.25 \mathrm{~mm} \text { ) }\end{array}$ & $\begin{array}{l}\text { Z. et.al } \\
2011 .\end{array}$ \\
\hline 7 & $\begin{array}{l}\text { FA content in pig meat (32 Prestice } \\
\text { Black-Pied aboriginal pigs and } 32 \\
\text { hybrid pigs Large White } x \text { Landrace } \\
\text { x Duroc x Pietrain). }\end{array}$ & $\begin{array}{l}\text { Assessment of the meat quality } \\
\text { of various animal genotypes. }\end{array}$ & $\begin{array}{c}\text { FA - GPC (6890N Agilent } \\
\text { Technologies })\end{array}$ & $\begin{array}{c}\text { Nevrkla } \\
\text { P. et.al } \\
2017 .\end{array}$ \\
\hline 8 & $\begin{array}{l}\text { AA and FA content in pig meat (30 } \\
\text { Landrace; } 30 \text { Landrace x Yorkshire; } \\
30 \text { Landrace } \times \text { Yorkshire x Duroc). }\end{array}$ & $\begin{array}{l}\text { Assessment of the meat quality } \\
\text { of various animal genotypes. }\end{array}$ & $\begin{array}{c}\text { AA - HPLC (LC-20 } \\
\text { Prominence, Shimadzu), FA } \\
\text { - GPC (Hewlett Packard). }\end{array}$ & $\begin{array}{c}\text { Neupoko } \\
\text { eva, A.S., } \\
2019 .\end{array}$ \\
\hline 9 & FA content in pig meat. & $\begin{array}{l}\text { Assessment of the meat quality } \\
\text { of various animal genotypes. }\end{array}$ & $\begin{array}{c}\text { FA - GPC by GOST P } \\
\text { 51483-9999 using Agilent } \\
\text { 7890A. }\end{array}$ & $\begin{array}{l}\text { Gurinovi } \\
\text { ch, G.V., } \\
\text { et al., } \\
2020 .\end{array}$ \\
\hline 10 & $\begin{array}{l}\text { FA content in pig meat (31 Landrace } \\
\text { breed). }\end{array}$ & $\begin{array}{l}\text { Assessment of the meat quality } \\
\text { by changes in the composition of } \\
\text { the diet (introduction of } \\
\text { microalgae supplements into the } \\
\text { diet in the amount of } 7 \% \text { and } \\
5 \% \text { ). }\end{array}$ & $\begin{array}{c}\text { FA - GPC (PerkinElmer } \\
\text { CLARUS 680) using a } \\
\text { capillary GC (Agilent, Santa } \\
\text { Clara). }\end{array}$ & $\begin{array}{l}\text { Kalbe, C., } \\
\text { et al., } \\
2019 .\end{array}$ \\
\hline 11 & $\begin{array}{l}\text { FA content in pig meat (594 pigs } \\
\text { Landrace } x \text { Yorkshire). }\end{array}$ & $\begin{array}{c}\text { Assessment of the meat quality } \\
\text { by changes in the composition of } \\
\text { the diet. }\end{array}$ & $\begin{array}{l}\text { FA - GPC (Agilent 6890N } \\
\text { GC, Agilent Technologies). }\end{array}$ & $\begin{array}{l}\text { Gjerlaug- } \\
\text { Enger, E., } \\
\text { et al., } \\
2014 .\end{array}$ \\
\hline 12 & $\begin{array}{l}\text { FA content in minced meat of pigs } \\
\text { and their products (sausages, hams, } \\
\text { etc.). }\end{array}$ & Assessment of the meat quality. & $\begin{array}{l}\text { FA - GPC (Agilent 7890A } \\
\text { Agilent Technolнологий). }\end{array}$ & $\begin{array}{l}\text { Pietrzak- } \\
\text { fiecko, R. } \\
\text { et.al. } \\
2014 .\end{array}$ \\
\hline 13 & $\begin{array}{l}\text { FA content in pig meat (60 Landrace } \\
\text { pigs, } 12 \text { in each group). }\end{array}$ & $\begin{array}{l}\text { Assessment of the meat quality } \\
\text { by changes in the composition of } \\
\text { the diet (adding flaxseed oil, } \\
\text { vitamin E and organic } \\
\text { selenium). }\end{array}$ & $\begin{array}{l}\text { FA - GPC (Agilent GC-7890 } \\
\text { Agilent Technologies Inc.). }\end{array}$ & $\begin{array}{l}\text { Wojtasik- } \\
\text { Kalinows } \\
\text { ka, I. } \\
\text { et.al., } \\
\text { 2018. }\end{array}$ \\
\hline 14 & $\begin{array}{l}\text { FA content in pig meat ( } 30 \text { samples } \\
\text { of meat from Polish breeds } \\
\text { Pulawskaya and a cross between } \\
\text { Pulawskaya x Landrace). }\end{array}$ & $\begin{array}{l}\text { Assessment of the meat quality } \\
\text { depending on the animal } \\
\text { husbandry system. }\end{array}$ & FA - GPC (Varian 450-GC). & $\begin{array}{l}\text { Karwows } \\
\text { ka, M., } \\
\text { et.al., } \\
\text { 2013. }\end{array}$ \\
\hline 15 & $\begin{array}{l}\text { FA content in pig meat ( } 60 \text { boletus of } \\
\text { the Korean breed) }\end{array}$ & $\begin{array}{l}\text { Assessment of the meat quality } \\
\text { depending on the animal } \\
\text { husbandry system. }\end{array}$ & FA - GPC (Varian 3,600). & $\begin{array}{l}\text { Kim, D.H } \\
\text { et.al., } \\
2009 .\end{array}$ \\
\hline
\end{tabular}


Notes: GPC - gas permeable chromatography, HPLC - high permeable liquid chromatography.

\section{The influence of fatty acid and amino acid composition of pig tissues on the formation of physical-chemical properties of meat}

Technological properties such as adipose tissue hardness, shelf life (oxidation of lipids and pigments) and aroma depend on the content of fatty acids in the tissue [34,35]. The authors [36] have shown that major SFA, such as stearic (18:0), palmitic (16:0) and myristic (14:0) acids, as well as the other SFA in small amount, such as margaric (17:0) and lauric (12:0) acids, give pork higher density and better taste. In addition these SFA are less susceptible to oxidation as UFA. It has been suggested [37] that the total amount of fatty acids, and not only the content of individual PUFAs, has a pronounced effect on the tenderness and juiciness of pork meat. The effect of fatty acids on hardness is due to the different melting points of fatty acids. For example, the stearic acid melts at a temperature of $+69.4^{\circ} \mathrm{C}$, margaric acid $-+60.6^{\circ} \mathrm{C}$, palmitic acid $-+64.0^{\circ} \mathrm{C}$, lauric acid $-+44.0^{\circ} \mathrm{C}$, oleic acid $\left(18: 1\right.$, cis-9) $-+14.0^{\circ} \mathrm{C}$, elaidic acid $(18: 1$, trans -9$)-+45.0^{\circ} \mathrm{C}$, linoleic acid $(18: 2)--5.2^{\circ} \mathrm{C}$ and linolenic acid $(18: 3)--11.3^{\circ} \mathrm{C}$ [5]. Thus, as the unsaturation degree of PUFAs increases, the melting point decreases. The isomeric structure of fatty acids is also important. For example, trans-isomers of FAs or "trans fatty" acids melt at a higher temperature than their predecessors (i.e. oleic acid as compared to stearic acid) [5]. Moreover, cis-isomers of FAs and branched chain fatty acids have a lower melting point than normal ("straight chain") fatty acids with the same number of carbon atoms (i.e. elaidic acid as compared to oleic acid) [5].

An influence of the composition and structure of fatty acids on the meat "shelf life" (i.e. time of validity) is explained by the fact that unsaturated fatty acids tend to oxidize the more, the greater the number of $\mathrm{C}=\mathrm{C}$ double bonds in a given particular FA [35-38]. This leads to the development of rancidity with increasing "shelf life". However, color change occurs not only because of FA oxidation, but also due to a number of other reasons [35-38]. For example, the reaction of the oxidation of oxymyoglobin (red-colored) to metmyoglobin (brown-colored) is usually occurs in parallel with rancidity. So, lipid oxidation products can promote pigment oxidation and vice versa that have been shown in the several studies [4,5,35-38]. All these findings are of great fundamental importance and practical value (but have not been fully understood yet) due to which a preparation of this review have been intended.

The effect of fatty acids on the taste of meat is due to the formation of volatile, odorous lipid oxidation products during cooking. The unsaturated fatty acids of phospholipids also play an important role in shaping the flavor of pork [38]. Early research showed that the fatty tissue in meat was the source of the characteristic species flavor [39].

Studies carried out in the period 1970-1980 have shown that the content of fatty acids C18: 0 and 18: 2 determines the elasticity of adipose tissue [35]. When the composition of fatty acids in meat was altered by changes in diet, genetics, gender, or body condition, these acids were highly correlated with elasticity measured subjectively (finger test) or objectively (using a compression tester or penetrometer). The role of the 18:0 to 18:2 ratio in predicting meat hardness is described by Whittington, F. M. et al. [40]. After slaughter, various changes favoring oxidation occur in pig meat, for example, the release of iron from cells and a decrease in the activity of the enzyme glutathione peroxidase [41]. Since pork contains a relatively large amount of unsaturated lipids, attempts to further increase the concentration of PUFA will increase a risk of the formation of a large number of oxidation products, leading to unpleasant odors, aromas and discoloration. This becomes the reason for the discussion of many authors [42,43,44].

Larick D. K. et al [45] showed that pork with a high content of C18:2 acids rapidly oxidizes when heated, forming various volatile compounds, including the aldehydes pentanal and hexanal. The authors [45] did not observe any changes in the aroma and color of minced pork products prepared from meats with low, as well as with high content of C18:2 fatty acids [45]. Hartman et al. [46] studied an increase in the concentration of C18:2 from $15 \%$ to $33 \%$ of the total amount of fatty acids in pork and found no significant effect on the taste and color of pork products [46]. Since pork contains a sufficiently high concentration of PUFAs (such as C18:2 and others), the products of their 
oxidation will influence the natural flavor of pork [47, 48]. The major results of the FA composition evaluation of pig muscle tissue are summarized in the Table 2.

Table 2. Content of the fatty acids in pork (according to some authors, cited in the last column).

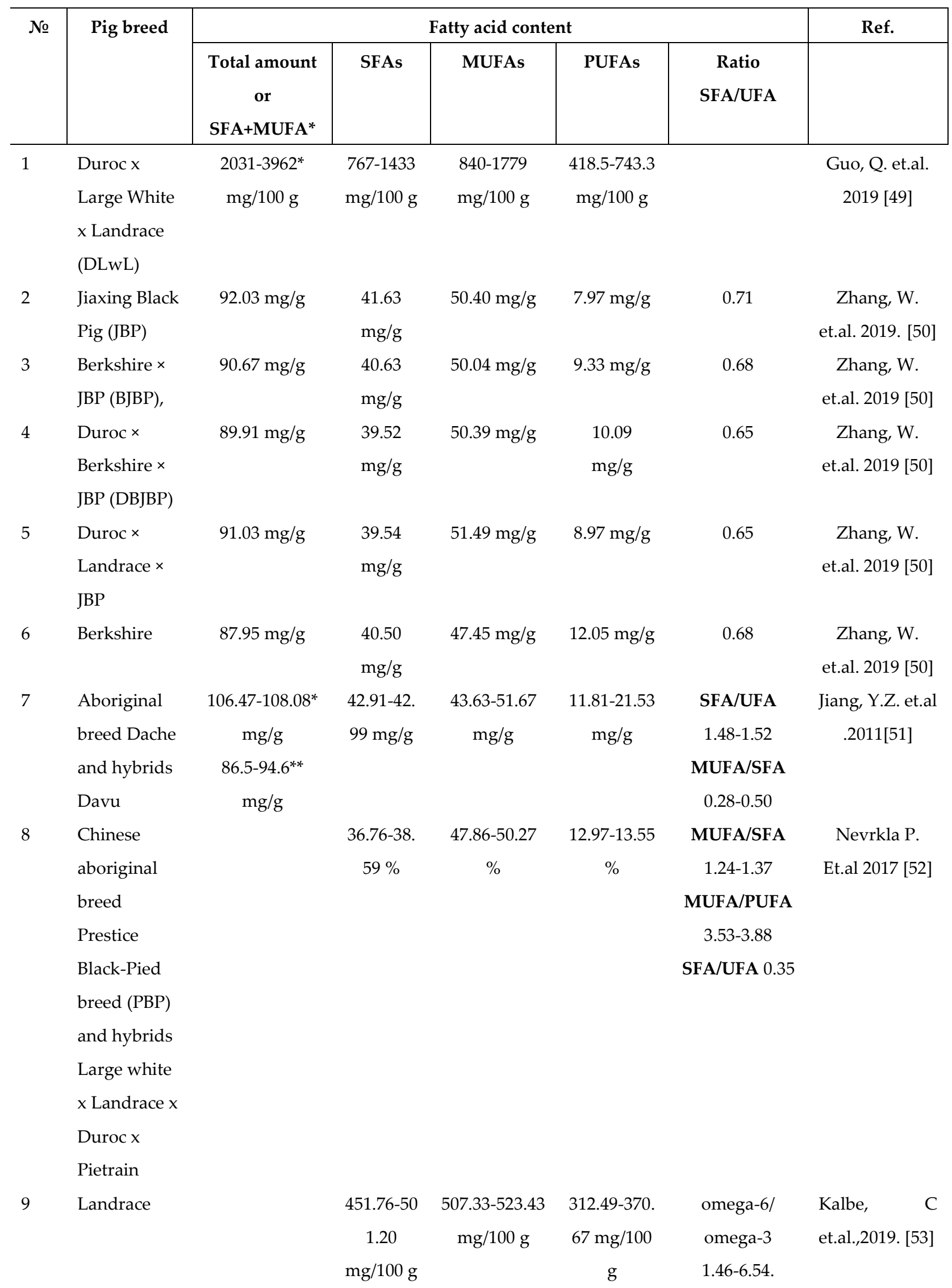




\begin{tabular}{|c|c|c|c|c|c|}
\hline \multirow[t]{4}{*}{ Landrace } & $41.6-44.9$ & $35.13-41.42$ & $12.57-19.98$ & MUFA/SFA & Wojtasik-Kalin \\
\hline & $9 \%$ & $\%$ & $\%$ & $1.23-1.41$ & owska, I. et.al., \\
\hline & & & & MUFA/PUFA & 2018. [54] \\
\hline & & & & $-3.59-4.62$ & \\
\hline Pulawskaya & $38.51-41$. & $53.16-58.04$ & $2.67-4.42 \%$ & & Karwowska, \\
\hline x Hybrid & $38 \%$ & $\%$ & & & M., et.al., 2013 \\
\hline Pulawskaya & & & & & [55] \\
\hline$x$ Landrace & & & & & \\
\hline Corean & $34.61-37$. & $42.48-48.37$ & $14.47-22.91$ & omega-6 / & Kim, D.H et.al. \\
\hline aboriginal & $16 \%$ & $\%$ & omega-3 & omega-3 & , 2009. [56] \\
\hline \multirow[t]{5}{*}{ breed } & & & 0.47-1.84, & 11.92-25.33. & \\
\hline & & & omega-614. & MUFA/PUFA & \\
\hline & & & $0-21.7 \%$ & $1.23-1.70$ & \\
\hline & & & & MUFA/SFA & \\
\hline & & & & $0.39-0.66$ & \\
\hline
\end{tabular}

Note $1:{ }^{*}$ calculated by the cited authors; ${ }^{* *}$ calculated by us.

Note 2: EFAs are saturated fatty acids, MUFAs are monounsaturated fatty acids, PUFAs are polyunsaturated fatty acids, EFAs / UFAs are the ratio of unsaturated fatty acids to unsaturated ones, UUFAs / EFAs are the ratio of unsaturated fatty acids to saturated ones, MUFAs / unsaturated fatty acids are the ratio of monounsaturated acids, PUFA / EFA is the ratio of polyunsaturated acids to saturated ones.

Note 3: Animal cross-breeds: Duroc $x$ Large White $x$ Landrace (DLwL); Jiaxing Black Pig (JBP), Berkshire $\times$ JBP $($ BJBP $)$, Duroc $\times$ Berkshire $\times$ JBP $($ DBJBP $)$, Duroc $\times$ Landrace $\times$ JBP $($ DLJBP $)$.

There are numerous authors determined the total FA content, as well as the fractions as EFA, MUFA, PUFA and their ratios in pork [39-47]. It should be noted that the genotype of animals leaves an imprint on the fatty acid composition of the muscle tissue of pigs. Thus, according to (Guo, Q.et.al 2019 [49]), the total content of fatty acids in the pig muscle tissues of cross-breeds Duroc x Large White $x$ Landrace is about $2031-3962 \mathrm{mg} / 100 \mathrm{~g}$ of meat (Table 2). According to another author (Jiang, Y. Z. et.al., 2011 [51]), the FA content in the muscles of Chinese aboriginal breeds was $106.47-108.08 \mathrm{mg} / \mathrm{g}$. The ratio of EFA to UFA in the muscle tissue of pigs of different genotypes ranges from 0.65 to 0.71 units. According to Wojtasik-Kalinowska, I. et.al. [54], the ratio of NUFA / EFA in the muscle tissue of Landrace pigs was 1.23-1.41 units, while according to Jiang, Y.Z et.al. [51], this indicator in pigs of indigenous Chinese breeds was higher and amounted to 1.48-1.52 units. The ratio of omega- 6 to omega-3 fatty acids is at the level of 1.46-25.33 units according to different authors [53-56] and also depends on genetic factors and conditions of animal farming.

Proteins of muscle tissue determine (to the greatest extent) its biological value, as well as the most important properties of meat in general (consistency, taste, color). The need to further study the amino acid profile of pig muscles is due to the fact that many of the amino acids are strong flavoring agents and amino acid analysis can predict the properties of finished products. The composition of muscle tissue includes proteins both: of muscle fibers and of the intercellular environment [3-5]. It is known that the muscle fiber proteins are part of the membrane (sarcolemma), nuclei, sarcoplasm, myofibrils and other structural elements of the cell [3-5]. They can be in a free state or associated with lipids, cations, glycogen, adenosine triphosphate (ATP) and other compounds [3-5]. Approximately 40\% of muscle tissue proteins are soluble in water (sarcoplasmic proteins and, partially, myofibril proteins) and above $40 \%$ - in solutions of potassium chloride of medium concentration (myofibril proteins) [57].

The indicators characterizing the biological value of AA content of proteins are developed by the FAO and WHO : standards of amino acid scale (1973, 1981, etc.), which simulates the "highly likely" calculated protein, i.e. so called "ideal" protein [10, FAO amino acid scoring patterns 1981 http://www.fao.org/3/M3013E/M3013E00.htm]; the digestible indispensable amino acid score 
(DIAAS) http://www.fao.org/ag/humannutrition/35978-02317b979a686a57aa4593304ffc17f06.pdf. Amino acids, presented in muscles, determine the taste of meat products [3-5,57-60]. For example, alanine, serine, threonine have a slightly sweet taste, while glycine, valine and proline are sweeter. Arginine, methionine, leucine, phenylalanine have a slightly bitter taste, while isoleucine, tryptophan, histidine and lysine have a bitter taste [57]. The composition of muscles contains the most glutamic acid and glutamine, which give "meaty" taste to meat [57]. Muscle proteins of pigs of various fatness differ in structure and amino acid content, which decreases with an increase in pork fat and a decrease in the amount of protein [57].

The numerous reactions between free amino acids and carbohydrates play an important role in the formation of the taste and aroma of meat, due to the multicomponent system of substances. At the same time, the amino acids that are bound to backbone in the long AA chain of biopolymer molecule do not affect significantly the taste and aroma of the product. Free nucleotides also belong to the substances involved in the formation of taste and aroma of meat. At the same duration of sterilization, the decrease in nucleotides and increase in nucleosides (inosine and hypoxanthine) and the total content of purine bases; the more intensive at higher sterilization temperature [58]. The presence of a specific smell during cooking and frying of various types of meat is due to the formed carbonyl compounds. The taste and aroma manifested when salting a meat product is due to the particular "conversion" of carbohydrates, lipids and amino acids, as well as the presence of a complex of organic compounds, which include purines, pyrimidines, creatine, creatinine and carboxylic acids [59].

The ratio of tryptophan to hydroxyproline is used as one of the most important criterions for the quality of meat products, as well as a protein quality indicator [60]. The higher this indicator, the higher the nutritional value of meat, the more muscle tissue, muscle proteins, and essential amino acids in the meat in total [60].

Table 3. The content of amino acid acids in pork (according to cited authors)

\begin{tabular}{|c|c|c|c|}
\hline № & Breed or cross & The total AA content & Refs. \\
\hline 1 & $\begin{array}{c}\text { Duroc x Large White } x \\
\text { Landrace }\end{array}$ & Free AA $69.35-73.93 \mathrm{mg} / 100 \mathrm{~g}$ & $\begin{array}{l}\text { Guo, Q.et.al 2019.- } \\
{[49]}\end{array}$ \\
\hline 2 & $\begin{array}{c}\text { Berkshire, Black Pig } \\
\text { (JBP), Berkshire × JBP } \\
\text { (BJBP), Duroc } \times\end{array}$ & The total AA content $19.06-21.15 \mathrm{mg} / 100 \mathrm{~g}$ & $\begin{array}{c}\text { Zhang, W. et.al. } 2017 . \\
\text { [68] }\end{array}$ \\
\hline & $\begin{array}{l}\text { Berkshire } \times \text { JBP }(\mathrm{DBJBP}) \text {, } \\
\text { Duroc } \times \text { Landrace } \times \mathrm{JBP}\end{array}$ & & \\
\hline
\end{tabular}

3 Chinese aboriginal breed Dache and

The total AA content 76.15-77.46, the amount of essential AA 30.16-30.64 mg/100 g

Jiang, Y. Z. et.al 2011 hybrids Davu

Landrace

The total AA content $21.701 \%$, the amount of non-essential AA $13.081 \%$

Neupokoeva, A.S. 2019[61]

$5 \quad$ Landrace $\mathrm{x}$ Yorkshire

The total AA content $22.419 \%$, the amount of non-essential AA13.546 \%

Neupokoeva, A.S. 2019[61] Duroc

The total AA content $22.561 \%$, the amount of non-essential AA $13.577 \%$

Neupokoeva, A.S. 2019 [61] 
Notes of the animal cross-breeds: Duroc $x$ Large White $x$ Landrace (DLwL); Jiaxing Black Pig (JBP), Berkshire $\times$ JBP $(B J B P)$, Duroc $\times$ Berkshire $\times$ JBP $($ DBJBP $)$, Duroc $\times$ Landrace $\times$ JBP $($ DLJBP) .

The contents of amino acids in the muscle tissue of pigs (according to some authors) are summarized in Table 2. It should be noted that the genotype of animals is also a determining factor influencing the amino acid composition of meat obtained from animals. It is amazing that the total amino acid content in muscles of aboriginal Chinese breeds and their crosses in the study by Jiang, Y.Z. et.al. (2011) [51] is 76.15-77.46 g / $100 \mathrm{~g}$ of meat. In the muscles of Jiaxing black pigs and their crosses with Berkshire, Duroc and Landrace, this indicator was at the level of 19.06-21.15 g / $100 \mathrm{~g}$ of muscle tissue. In the study of Neupokoeva, A.S. (2019) [61] in the muscle tissue of Landrace pigs and crosses with Yorkshire and Duroc, the total amount of amino acids was at the level of 21.701-22.561\% and did not depend on the animal genotype. The amount of non-essential amino acids for these pigs was at the level of $13.08-13.57 \%$ and almost the same between the studied groups.

\section{The influence of the most important factors on contents of pork fatty acids and amino acids 4.1 Influence of animal genotype}

The authors studied the influence of the genotype on the composition of the muscle tissue of animals [62-67]. Zhang W. and co-authors [68] studied the influence of animal genotype and hybridization of the local breed Jiaxing black pig (TsChS) with Western breeds on the slaughter, meat and taste qualities of products. The authors compared 5 breeds: TsChS, Berkshire, Berkshire $x$ TsChS (BTSChS), Duroc x Berkshire x TsChS (DBTSChS), Duroc x Landrace x TsChS (DLCChS). Heterosis was realized in the case of DTSChS, DBTSChS and DLCChS groups, since their carcass weight, percentage of leanness and the area of the "muscular eye" were noticeably higher as compared to the TsChS, but lower than that of the Berkshires. The internal fat content was the highest in the case of the TsChS pig group. For the hybrids of DBCCHS, muscle tissue had the highest content of essential amino acids, as well as their total amount [68].

The purposes of the experiment by Jiang Y. Z. et al. (2011) [51] were to compare the assess carcass growth and characteristics, organ weight, meat quality and intramuscular fatty acid content and amino acid composition between the Chinese Dahe Indigenous Pig and the Davou cross. Dahe pigs contained a higher percentage of carcass fat $(\mathrm{P}<0.001)$ compared to Davou pigs. The following fatty acids : C18: 1, C16: 0, C18: 0 and C18: 2 - prevailed in the muscle tissue of both pig breeds [51].

The study of Nevrkla P. et al. (2017) [52] is devoted to comparing the quality of meat of aboriginal pig breeds and hybrid crosses. A total amount of 64 animals are participated in the experiment, 32 pigs of the Prestice Black-Pied breed (PBP) and 32 pigs of the hybrid combination Large White $x$ Landrace $x$ Duroc $x$ Pietrain. Analysis of the fatty acid profile showed that there was a higher content of $C 8: 0(p \leq 0.01), C 10: 0(p \leq 0.01), C 15: 0(p \leq 0.01), C 22: 0(p \leq 0.01)$ 0.05), C18: 1 p-9

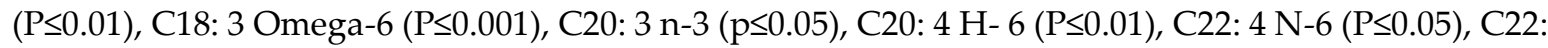
$5 \mathrm{n}-3(\mathrm{p} \leq 0.01)$ and C22: $6 \mathrm{n}-3(\mathrm{p} \leq 0.01)$ for hybrid animals than for PBP. The opposite trend was observed in the case of $\mathrm{C} 18$ : $1 \mathrm{n}-9(\mathrm{P} \leq 0.01)$ and $\mathrm{C} 20: 5 \mathrm{n}-3(\mathrm{p} \leq 0.01)$. Higher MUFA content as well as MUFA/SFA ratio was found in meat from PBP breed $(\mathrm{P} \leq 0.01)$. Higher levels $\mathrm{C} 10: 0$ ( $\mathrm{P} \leq 0.01), \mathrm{C} 12: 0$

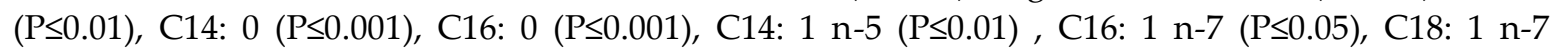
$(p \leq 0.001), C 20: 5 n-3(p \leq 0.01)$ and $C 22: 6 n-3(P \leq 0.05)$ were found in fat of hybrid pigs, however, $c 24$ :

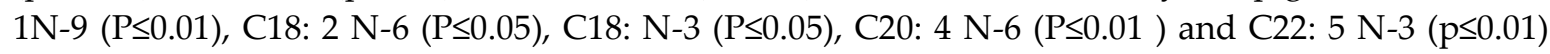
were higher in the case of PBP pigs.

Pig meat quality assessment (PMQA) of various genotypes was carried out in the work of Neupokoeva A.S. (2019) [61], in which the author assessed the biological and productive qualities of animals of Canadian selection in the Trans-Urals region. The author compared pigs of 3 genotypes animals of the Landrace Breed, Landrace X Yorkshire (LY), Landrace X Yorkshire X Duroc (LYD). The largest amount of essential amino acids was noted in muscle tissue samples of three-breed hybrids LYD (8.984\%), which is 0.364 and $0.111 \%$ more than in purebred Landrace and two-breed hybrids LY. The amino acid index and protein-quality indicator of the muscle tissue of three-breed hybrids are higher by 0.27 and $33.55 \%(\mathrm{P}<0.05)$ than in purebred Landrace and by 0.67 and $53.33 \%$ in comparison with two-breed hybrids, respectively [61]. 
When assessing the quality of muscle and adipose tissue obtained from pigs of various breeds, the authors determined that the fat of three-breed young was characterized by the lowest density and resistance to oxidation, where the Landrace breeds of Canadian selection and Belarusian meat were used as the paternal breeds (with a ratio of NUFA/NFA of 1.57:1 and 1.51:1). The content of the most valuable PUFA, arachidonic acid, was practically equal for animals of all studied hybrids $0.16-0.17 \%$. The Duroc breed has shown itself to be the best paternal breed among the studied, in terms of the effect on the technological and nutritional properties of the fat of the offspring, providing its higher density due to the lower ratio of unsaturated and saturated fatty acids -1.34 to 1 [63].

Sheiko R.I. (2019) [69] conducted research to study the quality of pig meat obtained by crossing sows of the Belarusian Large White and the Belarusian meat pig crossbred (BKBxBM) and Belarusian Large White sows with Yorkshire and Landrace breeds. The highest protein content in muscle tissue was observed in young growth (BKBxBM) $x D-20.9$ and $(B K B \times B M) \times L-21.2 \%$, respectively. The amino acid rate for all the studied amino acids was in the range of $111.3-191.4 \%$, which indicates the content of all high-quality complete protein combinations in the young pig. In the studied samples of adipose tissue, the content of saturated fatty acids (SFA) was 38.7-45.9\%, monounsaturated fatty acids (MUFA) - 44.1-46.8\%, polyunsaturated fatty acids (PUFA) - $12.0-14.5 \%$ [39].

Wood J. D et al. (2004) [70] reported that the breed affects the PMQA of pigs. Pork obtained from animals of the Yorkshire breed (more fatty carcasses) had a higher concentration of C 14:0 and C 16:0, while meat obtained from the Duroc and Large white pigs (more meat carcasses) contained more polyunsaturated fatty acids. The meat of the Duroc pig had high concentrations 20:5 $\omega-3$ and 22:6 $\omega-3$ [70]. The study of the influence of the genotype on the quality of meat, in particular fatty acid and AC of pork, are also devoted to the work of other authors [71,72].

\subsection{Conditions for keeping animals}

Consumers are now becoming more demanding about food, choosing safe and quality food sources to maintain and improve their health. In this regard, the production of so-called "organic " products has grown in recent years, because they are in great demand as food products [73]. It is believed that the introduction of the system of "organic pork" production contributes to obtaining not only high-quality products, but also with a higher nutritional value [74,75]. According to some authors, there are differences in fatty acid composition between meat obtained as a result of "organic pork" production and from animals raised under traditional conditions [76]. The authors report on the advantage of "organic pork" in terms of a higher content of polyunsaturated fatty acids in such meat and a lower content of saturated ones [77]. Other authors report that the meat of pigs raised using "organic pork" production is significantly richer in $\alpha$-linolenic acid and the total amount of polyunsaturated fatty acids and has a more favorable ratio of acids $\omega-3$ to $\omega-6$ [78]. The results obtained by the authors indicate that "organic" meat may be more prone to lipid oxidation [75, 77].

The work of Karwowska M. et al. (2013) [55] is devoted to a comparison of the quality of meat of animals raised in organic production and under normal conditions. The authors showed that "organic" pig meat was characterized by higher lipid stability during the entire shelf life compared to meat obtained from animals raised under normal production conditions.

Kim D.H. et al (2009) also studied the effect of feeding and housing under traditional and organic conditions on carcass performance, meat quality, and longissimus muscle of Korean pigs (n $=30)$. Organic content contributed to the production of pork $(\mathrm{Pb} 0.05)$ with a higher content of polyunsaturated fatty acids (PUFA) and unsaturated fatty acids, as well as a higher content of N-3 PUFA than regular (Pb0.05) Content (\%) EFA 34.61 -37.16, NNFA - 62.84-65.36, MNFA - 42.48-48.37, PUFA - 14.47-22.91, omega -3 PUFA 0.47-1.84, $\omega$-6 PUFA 14.0-21.7, $\omega 6$ / $\omega 3$-11.92-25.33, MUFA / EFA -1.23-1.70, PUFA / EFA - 0.39-0.66 [56].

Grela, E.R. and Kowalczuk, E. (2009) analyzed the nutrient content and fatty acid profile of meat from conventional and organic pigs. Meat from organically grown pigs had a higher nutrient content than that from conventional pigs [78].

The influence of the keeping system on the quality of meat was also studied in her work by Semenikhina T.V. and coauthors (2012). Their research was devoted to the study of the quality 
indicators of meat obtained from pigs raised in pig farms and private farmsteads. Pork obtained from animals raised on pig farms contained a higher amount of protein in muscle tissue due to balanced feeding, which allows intensifying pork production by increasing the biological and nutritional value, in particular protein and essential amino acids [79].

\subsection{Animal age}

It is known that $\mathrm{AA}$, taste and tenderness of meat are finally formed in pigs by 8 months, when their live weight reaches $100-112 \mathrm{~kg}$. In the carcasses of older pigs, there is a significant mass of adipose tissue that is not desirable for the product quality, as well as the formation of more fat than muscles [57].

With the age of animals, as the subcutaneous fatty tissue develops and changes in its composition, it becomes more "condensed", without a clear separation of layers. The separation of layers in the adipose tissue of pigs is undesirable, since it spoils the presentation of fresh meat and products from it. Studies have shown that the connectivity of adipose tissue, as well as the toughness of meat, closely correlates with the content of water, collagen, the concentration of fatty acids C 18: 0 and C 18: 2 [41].

\subsection{Changes in the composition of pig meat under various storage and processing conditions}

Various authors have evaluated the AA of meat under different storage conditions. So, Knyazeva A.S. and co-authors (2017) [80] evaluated the change in the amino acid composition of meat protein during long-term storage of raw materials at low temperatures. The main effect on the change in the protein substances of meat and the amino acid composition associated with them is exerted by the freezing process. A significant result of this storage can be protein denaturation and aggregation, but the subsequent storage of meat in a frozen state has a lesser effect on these changes. It was found that the most significant changes occur during storage of frozen meat for more than 180 days of storage, which can affect its technological properties. By meat storing for more than 480 days, methionine became the limiting amino acid for pork [80].

Pietrzak-fiecko R. and co-authors (2014) [81] compared the FA content of minced meat and various meat products - in ham, sausage. Among all fatty acids contained in meat products, the largest share falls on C18: $1 \mathrm{n}-9, \mathrm{C} 16: 0, \mathrm{C} 18: 0, \mathrm{C} 18: 2 \mathrm{H}-6$ and C16: 1. PUFA makes up 8.7, 9.2 and 9\% of the total amount of fatty acids, and linolenic acid $-0.6,0.7$ and $0.3 \%$ in ham, sausages and minced meat, respectively. Minced meat had the highest $\omega-6 / \omega-3$ ratio (22.5) compared to ham and sausages (15.5 and 13.9, respectively [81].

Gurinovich G.V. and co-authors (2020) [82] studied the composition of pork according to the carcass category. The objects of research were "uncooked" smoked hams of two groups: 1) the first group hams are made from raw materials based on cutting carcasses of pigs of the 4th category, 2) the second group hams - from raw materials based on cutting carcasses of sows of the 2nd category. For cutting experiments, 3 carcasses of each category weighing 225-240 kg (category 4) and 54-63 kg (category 2) were taken [82]. The study showed that the process of fermentation of raw smoked hams (made from raw materials) from the cutting of heavy sow carcasses develops traditionally, as evidenced by the results of determining the active acidity, weight loss and water activity. Fermented hams are characterized by higher protein content than hams made from "young" meat under similar conditions. The peculiarities of the fatty acid composition of minced ham contribute to a more intensive development of the lipid degradation process. This is evidenced by the results of determination of free fatty acids, primary and secondary oxidation products, which did not have a negative impact on the organoleptic properties of hams and safety indicators [82].

Summarizing the data discussed above, we can conclude that genotypic and phenotypic factors affect the quality of meat. Obtaining high quality livestock products, rich in essential nutrients, is currently very relevant and in demand, due to the influence of the composition of meat on the health of the population consuming products. In this regard, the development of strategies for the enrichment of livestock products with nutrients and obtaining high-quality functional meat is paid much attention in the works of numerous authors [83-91] that will be discussed below.

\subsection{Regulation of pork composition using nutritional factors}

Several authors $[64,65,69]$ have noted that the addition of various oils to pig diets is an effective way to alter the fatty acid composition of pork. The possibility of modifying intramuscular fat in 
pork can lead to an increase in the proportion of unsaturated fatty acids [64]. Some authors [65, 69] report that feeding animals with diets rich in fat usually results in higher levels of PUFA in muscle, but this affects negatively the taste of the product [65]. So, the lipid composition of the diet of animals has a decisive effect on the taste of meat obtained from them [69].

Wojtasik-Kalinowska I. et al. (2018) [54] studied the fatty acid profile of the muscle tissue of Landrace pigs after feeding a diet with various ingredients. The results showed that when the main diet was fed to animals with the addition of $3 \%$ flaxseed oil, $100 \mathrm{mg}$ per $\mathrm{kg}$ vitamin $\mathrm{E}$ and $1 \mathrm{mg}$ per $\mathrm{kg}$ organic selenium, the level of polyunsaturated fatty acids (PUFA) in meat samples was $26 \%$ higher $(\mathrm{P} \leq 0.05)$ as compared to control [54]. By adding the fat flaxseed (5\%) in diets for "organic pork" production increased significantly the level of linolenic acid in muscle fat, as compared to animals fed conventional diets supplemented with $2 \%$ soybean oil [51].

Several other studies $[68,69,71]$ have examined the effect of the inclusion of various oils (such as soybean, peanut, corn and sunflower oils), containing a high proportion of C18:2 fatty acids in animal diets on the acid composition and quality of pork. Studies have shown that the concentration of C18:2 acids in meat can be easily raised from about $10-15 \%$ fatty acids to over $30 \%$ with these nutritional factors $[68,69,71]$.

Changing the diet of pigs by adding C18:3 fatty acids (from rapeseed and linseed oils) has been studied in the works of several authors [73-75] in order to reduce the ratio $\omega-6 / \omega-3$. In some studies, the authors did not note any negative changes in meat quality when these products were included in animal diets [74], while in others, the meat had an unpleasant odor and taste, especially when salt was added, chopped, frozen, and reheated [75]. Campo M. M. et al. (2003) showed that C 18:3 fatty acids produce more intense odors than C18:2. [91]. Several authors [83-85] reported a positive effect of antioxidants fed together with sources of fatty acids to improve the fatty acid composition of pork, as well as the meat quality during storage.

Several other authors have studied ways to improve the quality and oxidative stability of pork using nutritional factors [92-97].

Hwang, Y. H. et al (2010) [95] fed Landrace x Yorkshire $x$ Duroc hybrids with different doses of "betaine" 40 days before slaughter. The study of the fatty acid composition of pork showed that changes in the composition of the diet contributed to an increase in the proportion of saturated fatty acids and a decrease in unsaturated ones [95].

Zhong, J.-F. et al (2018) [96] fed Landrace $x$ Yorkshire $x$ Duroc hybrids for 30 days with a probiotic complex consisting of inactivated bacteria of the genus Mycobacterium phlei, which has immune-stimulating properties. Fatty acid analysis of the Longissimus dorsi showed a slight decrease in saturated and an increase in monounsaturated and polyunsaturated fatty acids. At the same time, an improvement in the quality of meat was observed with an increase in the content of intramuscular fat due to the inactivation of some genes [96].

The optimal content of fatty acids in the muscles (both, from neutral fats and phospholipids) and the presence of many fatty layers passing through the entire pulp, which forms a "marble pattern" in the meat (called "marbling" in cooking), determines all the meat quality indexes, especially - juiciness and tenderness.

Guo Q. et.al. (2019) [49] studied the effect of such "functional" amino acid as arginine on the quality of meat. In the diet of 60 growing and fattening pigs (Duroc $x$ Large white $x$ Landrace) during 2 months before slaughter: $1.0 \%$ of arginine and glutamic acid were additionally introduced. After the slaughter of animals, a comparative study of AA and FA profiles in muscles was carried out. It was shown that these fed supplements had an insignificant effect on the content of free amino acids, did not affect the content of 5-nucleotides and the taste of meat. The addition of arginine and glutamic acid significantly increased $(\mathrm{P}<0.05)$ the accumulation of fat and the content of fatty acids in the muscles, promoted an increase $(\mathrm{P}<0.05)$ in the formation of fatty acid oxidation products, improved tenderness and juiciness of meat. This study [49] showed that feed additives containing $1.0 \% \mathrm{~L}$-arginine and glutamic acid can be used to improve the quality of pork.

The use of arginine feed additives for animals promoted an increase in intramuscular fat [79], muscle growth and reduced fat accumulation in pigs [80], improving meat quality and yield. It was 
also noted that the addition of arginine to diets lowers the regulation of glycolysis in muscles after slaughter and increases the $\mathrm{pH}$ (from 4 to 5 units) in muscles during slaughter [80].

Kalbe C. et al (2018) [53] investigated the effect of long-term intake of microalgae supplements ( $7 \%$ in the diet of piglets and $5 \%$ in the diet of fattening) on the muscle microstructure and meat quality, including FAs in Landrace gilts $(\mathrm{n}=31)$. An increase in the concentration of $\omega-3$ and $\omega-6$ polyunsaturated fatty acids (PUFA) was found, which led to an increase in the accumulation of docosahexaenoic acid (DHA) and eicosapentaenoic acid (EPA) in the meat of pigs receiving this supplement [53].

The inclusion of dry apple pomace (of $10-20 \%$ of the nutritional value of the main diet) in the diet of fattening pigs, as a partial substitute for compound feed, did not have a significant effect on the amino acid composition of pork, but contributed to a significant increase in the content of valine, methionine, isoleucine, leucine, phenylalanine, serine and cystine in meat [82].

In the works of other authors, attention is paid to the amino acid composition of animal muscle tissue [98-104].

Thus, the lifetime formation of high quality pork is possible by using various nutritional factors in the diets of animals, which, according to many authors, can serve to change the composition, taste and technological properties of meat, especially the FA content and their ratio. The comparative changes in the amino acid composition of pork by changing the diets of cross-breed animals are almost not shown in the available literature sources.

\section{Conclusions}

Meat is a source of proteins (including peptides and amino acids), fat (including triacylglycerols and other lipids), numerous mineral and extractive substances, vitamins, the presence of which is necessary for the normal functioning of the body. The quality of pork, including its chemical and technological properties, largely depends on the amino acid composition of muscle tissue, as well as content and the particular ratios of various fatty acids in pork fat.

It is important to highlight that the total amount of fatty acids has the greatest effect on the tenderness and juiciness of pork meat, and not only the content of individual PUFAs. The effect of fatty acids on hardness is due to the different melting points of fatty acids. The effect of fatty acids on the taste and color of meat is due to the formation of lipid oxidation products during cooking and technological procedures.

Vital enrichment of the nutritional composition of pig meat is currently very important, since it is the basis of technologies for providing humans with healthy, safe and high-quality food of animal origin and contributes to the preservation and improvement of the human environment. By changing the nutritional factors, it is possible to regulate the fatty acid composition of the adipose and muscle tissue of pigs.

The main methods for determining the fatty acid and amino acid contents are the following: gas chromatography and ion-exchange chromatography, respectively.

Author Contributions: Conceptualization, Z.S.Yu. and B.N.V.; methodology, B.N.V.; validation, Z.S.Yu.; investigation, Z.S.Yu. and B.N.V.; resources, B.N.V.; data curation, Z.S.Yu. and B.N.V.; writing-original draft preparation, Z.S.Yu. and B.N.V.; writing - review and editing, Z.S.Yu. and B.N.V.; supervision, B.N.V.; project administration, Z.S.Yu.; funding acquisition, Z.S.Yu. All authors have read and agreed to the published version of the manuscript.

Funding: This research was supported by the Russian Science Foundation (grant number No. 20-16-00032).

Acknowledgments: The authors are thankful to O.A. Voronina and D.D. Plotnikov for technical support.

Conflicts of Interest: The authors declare no conflict of interest.

The funders had no role in the design of the study; in the collection, analyses, or interpretation of data; in the writing of the manuscript, or in the decision to publish the results.

\section{References}

1. Ernst, L.K.; Zinovieva, N.A. Biological problems of animal husbandry in the XXI century. Moscow: RAAS, 2008, 501 p. 
2. Kharitonov, E.L. Experimental-applied physiology of digestion of ruminants. Borovsk, Dubrovitsy : Publishing house “L.K. Ernst Federal Research Center for Animal Husbandry" 2019, 448 p.

3. Kaneko, J.J.; Harvey, J.W.; Bruss, M.L. Clinical Biochemistry of Domestic Animals, 6th ed. Amsterdam: Elsevier 2008,916 p.

4. Aliev, A.A.; Aitova, M.D.; Gabel, M. Metabolism in ruminants. Moscow: RAAS, 1997.

5. Zaitsev, S.Yu. Biological chemistry: from biologically active substances to organs and tissues of animals. Moscow: Publishing house "Capital Print", 2017, 507 p.

6. Vongsawasdi P.; Noomhorm A. Bioactive compounds in meat and their functions. Functional foods and diet supplements. In: Functional foods and dietary supplements: processing effects and health benefits. A. Noomhorm, I. Ahmad, A.K. Anal (eds). John Wiley \& Sons, Ltd, Oxford, 2014.

7. Alekseev, A.L.; Kryshtop, E.A.; Barilo, O.R.; Sagnitaeva, S.R. AS of muscle tissue of pigs of various breeds and types of the Rostov region. Agrarian Bulletin of the Urals 2011, 3(82), 24-25.

8. Bruhat, A.; Cherasse, Y.; Chaveroux, C.; Maurin, A.C.; Jousse, C.; Fafournoux, P. Amino acids as regulators of gene expression in mammals. Molecular mechanisms.Biofactors 2009, 35(3), 249-257.

9. Wu, G. Functional amino acids in growth, reproduction, and health. Advances in Nutrition 2010, 1(1), 31-37.

10. Le Floc'h, N.; Wessels, A.; Corrent, E.; Wu, G.; Bosi, P. The relevance of functional amino acids to support the health of growing pigs. Animal Feed Science and Technology. 2018, 245, 104-116.

11. Williams, C.M. Dietary fatty acids and human health. Annales Zootechnie 2000, 49(3), 165-180.

12. Mikhailov, N.V.; Svinarev, I.Yu.; Goncharov, A.Yu. Meat quality of three-breed hybrids. Livestock in Russia 2011, 3, 25-26.

13. Jain A., Jain R., Jain S. Paper Chromatography of Amino Acid. In: Basic Techniques in Biochemistry, Microbiology and Molecular Biology. Springer Protocols Handbooks. Humana, New York. 2020. https://doi.org/10.1007/978-1-4939-9861-6 59

14. Majhi K.C., Karfa P., Madhuri R. Chromatographic Separation of Amino Acids. In: Applications of Ion Exchange Materials in Biomedical Industries. Springer, Cham. 2019. https://doi.org/10.1007/978-3-030-06082-4_4

15. Marrubini, G.; Appelblad, P.; Maietta, M.; Pappetti, A. Hydrophilic interaction chromatography in food matrices analysis: An updated review. Food Chem. 2018, 258, 53-66.

16. Cacciola, F.; Dugo, P.; Mondello, L. Multidimensional liquid chromatography in food analysis. TrAC. 2017, 96, 116-123.

17. D Orazio, G.; Fanali, C.; Assensio-Ramos, M.; Fanali, S. Chiral separations in food analysis. TrAC. 2017, 96, 151-171.

18. Nunez, O.; Gallart-Ayala, H.; Martins, C.P.B.; Lucci, P. New trends in fast LC for food and environmental analysis. J. Chromat. A 2012, 1228, 298-323.

19. Pan, H-B.; Zhang, D.; Li, B.; Wu, Y-Y.; Tu, Y-Y. A rapid UPLC method for simultaneous analysis caffeine and 13 index polyphenols in black tea. J. Chromat. Sci. 2017, 55, 495-496.

20. Guillen-Casla, V.; Rosales-Conrado, N.; Leon-Gonzales, L. Determination of serotonin and its precursors in chocolate samples by capillary liquid chromatography with MS detection. J. Chromat. A 2012, 1232, $158-165$.

21. Finalli, C.; Dugo, L.; Dugo, P.; Mondello, L. Capillary-LC andnano-LC in food analysis. TrAC. 2013, 52, 226-238.

22. Peris-Vicente, J.; Albiol-Chiva, J.; et al. Advances on melamine determination by micellar liquid chromatography - a review. J. Liquid Chrom. 2016, 39, 325-338.

23. Jandera, P. Advances in the development of organic polymer monolithic columns and their application in food analysis- a review. J. Chromat. A 2013, 1313, 37-53. 
24. Nasa, J.L.; Ghelardi, E.; Degano, I.; et al. Core shell stationary phases for a novel separation of triglycerides in plant oils by HPLC with ES-quadrupols-time of fligt MS. J. Chromat. A 2013, 1308, 114-124.

25. Dzantiev, B.B.; Bysova, N.A.; Urusov, A.E.; Zherdev, A.V.Immunochromatographic methods in food analysis. TrAC. 2014, 55, 81-93.

26. Armenta, S.; de la Guardia, M. Green chromatography for the analysis of foods of animal origin. $\operatorname{Tr} A C$. 2015, 80, 517-530.

27. Yashin, Ya.; Vedenin, A.; Yashin, A. HPLC and ultra-HPLC: state of the art and prospects. Analytics. 2015, $2,70-84$.

28. Zakharov, A.M.; Grinshtein, I.L.; Kartsova, L.A. Determination of amino acids in dry cow brain extract, calf and chicken meat samples by high performance liquid chromatography. Sorption and chromatographic processes 2012, 12(6), 845-853.

29. Sadek P. HPLC Solvents. Moscow; 2006.

30. Poboży, E.; Czarkowska, W.; Trojanowicz, M. Determination of amino acids in saliva using capillary electrophoresis with fluorimetric detection. Journal of Biochemical and Biophysical Methods. 2006, 67(1), 37-47.

31. Dudkina, N.N.; Bespamyatnykh, E.N.; Lysov, A.V.; Busygin, P.O. Determination of amino acids in tissues and organs of pigs by reversed-phase high-performance liquid chromatography. Regulatory issues in veterinary medicine. 2017, 3, 171-173.

32. Rudenko, A.O.; Kartsova, L.A.; Snarsky, S.I. Determination of the most important amino acids in complex objects of biological origin by the method of reversed-phase HPLC to obtain amino acid phenylthiohydantoins. Sorption and chromatographic processes 2010, 10(2), 223-230.

33. Kambhampati, S., Li, J., Evans, B.S. et al. Accurate and efficient amino acid analysis for protein quantification using hydrophilic interaction chromatography coupled tandem mass spectrometry. Plant Methods, 2019, 15: 46. https://doi.org/10.1186/s13007-019-0430-z

34. Palmquist, D.L. Omega-3 Fatty Acids in Metabolism, Health, and Nutrition and for Modified Animal Product Foods. The Professional Animal Scientist 2009, 25(3), 207-249.

35. Wood, J.D.; Richardson, R.I.; Nute, G.R.; Fisher, A.V.; Campo, M.M.; Kasapidou, E. Effects of fatty acids on meat quality: a review. Meat Science 2004, 66(1), 21-32.

36. Zabolotnaya, A.A.; Bekenev, V.A. Physicochemical properties of pig fat of different origins. Pig breeding 2011, 4, 16-18.

37. Enser, M. The chemistry, biochemistry and nutritional importance of animal fats. London, 1984.

38. Renerre M. Oxidative processes and myoglobin. In: Antioxidants in Muscle Foods: Nutritional Strategies to Improve Quality / E. Deker, C. Faustman, C. J. Lopez-Bote (Eds.). John Wiley \& Sons: Hoboken, NJ, 2000.

39. Mottram, D.S. Flavour formation in meat and meat products: a review. Food Chemistry 1998, 62(4), 415-424.

40. Whittington, F.M.; Prescott, N.J.; Wood, J.D.; Enser, M. The effect of dietary linoleic acid on the firmness of backfat in pigs on 85kg live weight. Journal of the Science of Food and Agricultural 1986, 37(8), 753-761.

41. Wood, J.D.; Enser, M.B.; MacFie, H.J.H.; Smith, W.C.; Chadwick, J.P.; Ellis, M. Fatty acid composition of backfat in Large White pigs selected for low backfat thickness. Meat Science 1978, 5(2), 289-300.

42. Martini Serena, Tagliazucchi Davide, Minelli Giovanna, Lo Fiego Domenico Pietro, Influence of linseed and antioxidant-rich diets in pig nutrition on lipid oxidation during cooking and in vitro digestion of pork, Food Research International, 2020, 137, 109528. 10.1016/j.foodres.2020.109528.

43. AlbuquerquE T.M., Ramos E.M., Machado I. F., Borges P.C., Bolleta A.G., Marçal J.O., de Carvalho F. P., Faria P.B., Lipid profile and quality of meat from finishing pig supplemented with minerals. Food Science and Technology, 2019, 10.1590/fst.06118. 
44. Skaperda Z., Veskoukis A.S., Kouretas D. Farm animal welfare, productivity and meat quality: Interrelation with redox status regulation and antioxidant supplementation as a nutritional intervention (Review). World Academy of Sciences Journal, 2019, 1:177-183.

45. Larick, D.K.; Turner, B.E.; Schoenherr, W.D.; Coffey, M.T.; Pilkington, D.H. Volatile compound contents and fatty acid composition of pork as influenced by linoleic acid content of the diet. Journal of Animal Science 1992, 70(5): 1397-1403.

46. Hartman, A.D.; Costello, W.J.; Libal, G.W.; Walhlstrom, R.C. Effect of sunflower seeds on performance, carcass quality, fatty acids and acceptability of pork. Journal of Animal Science 1985, 60(1): 212-219.

47. De Tonnac A., Mourot J. Effect of dietary sources of n-3 fatty acids on pig performance and technological, nutritional and sensory qualities of pork. Animal, 2018, 12 (7), 1527-1535.

48. Leikus R., Juskiene V., Juska R., R. Juodka, D. Stankeviciene, R. Nainiene, A. Siukscius Effect of linseed oil sediment in the diet of pigs on the growth performance and fatty acid profile of meat. Revista Brasileira de Zootecnia, 2018, 47, e20170104.

49. Guo, Q.; Kong, X.; Hu, C.; Zhou, B.; Wang, C.; Shen, Q.W. Fatty Acid Content, Flavor Compounds, and Sensory Quality of Pork Loin as Affected by Dietary Supplementation with 1-arginine and Glutamic Acid. Journal of Food Science 2019, 84(12), 3445-3453.

50. Zhang, W.; Song, Q.; Wu, F.; Zhang, J.; Xu, M.; Li, H.; Xu, N. Evaluation of the four breeds in synthetic line of Jiaxing Black Pigs and Berkshire for meat quality traits, carcass characteristics, and flavor substances. Animal Science Journal. 2019, 90(4), 574-582.

51. Jiang, Y.Z.; Zhu, L.; Li, X.W.; Si, T. Evaluation of the Chinese indigenous pig breed Dahe and crossbred Dawu for growth and carcass characteristics, organ weight, meat quality and intramus-cular fatty acid and amino acid composition. Animal 2011, 5(9), 1485-1492.

52. Nevrkla, P.; Kapelański, W.; Václavková, W.E.; Hadaš, Z.; Cebulska, A. Meat quality and fatty acid profile of pork and backfat from an indigenous breed and a commercial hybrid of pigs. Annals of Animal Science 2017, 17(4), 1215-1227.

53. Kalbe, C.; Priepke, A.; Nürnberg, G.; Dannenberger, D. Effects of long-term microalgae supplementation on muscle microstructure, meat quality and fatty acid composition in growing pigs. Journal of Animal Physiology and Animal Nutrition 2018, 103(2), 101-111.

54. Wojtasik-Kalinowska, I.; Guzek, D.; Górska-Horczyczak, E.; Brodowska, M.; Sun, D.-W.; Wierzbicka, A. Diet with linseed oil and organic selenium yields low n-6/n-3 ratio pork Semimembranosus meat with unchanged volatile compound profiles. International Journal of Food Science \& Technology 2018, 53(8), 1838-1846.

55. Karwowska, M.; Dolatowski, Z.J. Comparison of lipid and protein oxidation, total iron content and fatty acid profile of conventional and organic pork. International Journal of Food Science E Technology 2013, 48(10), 2200-2206.

56. Kim, D.H.; Seong, P.N.; Cho, S.H.; Kim, J.H.; Lee, J.M.; Jo, C. Fatty acid composition and meat quality traits of organically reared Korean native black pigs. Livestock Science 2009, 120(1-2), 96-102.

57. Rogozhin, V.V. Biochemistry of milk and meat. SPb., 2012.

58. Negreeva, A.N.; Yurieva, E.V.; Khlupov, A.A.; Ushakova, I.Yu. Influence of unconventional feed on pork. Materials of inter. scientific-practical conf. "Modern technologies in animal husbandry: problems and solutions." Michurinsk, 2017, 59-63.

59. Tatulov, Yu.V.; Voskresensky, S.V. Standardization of the production of high quality pork. Meat Industry 2005, 4, 44-46.

60. Rogov, I.A.; Antipova, L.V.; Dunchenko, N.I. Chemistry of food. Moscow, 2007. 
61. Neupokoeva, A.S. Productive and biological qualities of pigs of Canadian selection in the conditions of the Trans-Urals. Cand. dis. G. Kurgan, 2019.

62. Velichko, V.A.; Patieva, A.M. The influence of the genotype on the nutritional value of pig meat. Proceedings of the Kuban State Agrarian University 2011, 31, 254-258.

63. Rudishin, O.Yu.; Burtseva, S.V. Morphological composition of carcasses and technological properties of pig fat. Meat Industry, 2009, 7, 58-60.

64. Burmistrov, V.; Pustovit, I. Physico-chemical composition of muscle and adipose tissue in pigs of different genotypes. Pig breeding 2005, 2, 14-16.

65. Dailidov, V.A. Nutritional value of muscle and qualitative composition of adipose tissue of young fattening pigs obtained with the participation of Belarusian and foreign breeds. In the conf. collection: Actual problems of intensive development of animal husbandry. Gorki, 2019, 56-62.

66. Palma-Granados, P., Lara, L., Seiquer, I., Aguilera, J. F., \& Nieto, R. Genotype and dietary lysine deficiency affect carcass and muscle amino acid composition of pigs growing from 10 to $25 \mathrm{~kg}$ body weight. Journal of Animal Physiology and Animal Nutrition, 2019, 00, 00:1-9. doi:10.1111/jpn.13176.

67. Liu, Y., Li, F., Kong, X., Tan, B., Li, Y., Duan, Y., Yin, Y. Signaling pathways related to protein synthesis and amino acid concentration in pig skeletal muscles depend on the dietary protein level, genotype and developmental stages. PLoS ONE, 2015, 10, e0138277.

68. Zhang, J.; Chai, J.; Luo, Z.; He, H.; Chen, L.; Liu, X.; Zhou, Q. Meat and nutritional quality comparison of purebred and crossbred pigs. Animal Science Journal, 2017, 89(1), 202-210.

69. Sheiko, R.I. Growth energy and meat qualities of pigs of various genotypes. Scientific notes of the educational institution Vitebsk Order Badge of Honor State Academy of Veterinary Medicine. 2019, 55(1), 160-166.

70. Wood, J.D.; Nute, G.R.; Richardson, R.I. Effects of breed, diet and muscle on fat deposition and eating quality in pigs. Meat Science. 2004, 67(4), 651-667.

71. Franco, D.; Vazquez, J.A.; Lorenzo, J.M.. Growth performance, carcass and meat quality of the Celta pig crossbred with Duroc and Landrance genotypes. Meat Science. 2014, 96(1), 195-202.

72. Bonneau, M.; Lebret, B. Production systems and influence on eating quality of pork. Meat Science. 2010, 84(2), 293-300.

73. Alfaia, C.P.M.; Alves, S.P.A.; Martins, S.I.V.; Costa, A.S.H.; Fontes, C.M.G.A.; Lemos, J.P.C.; Bessa, R.J.B.; Prates, J.A.M. Effect of the feeding system on intramuscular fatty acids and conjugated linoleic acid isomers of beef cattle, with emphasis on their nutritional value and discriminatory ability. Food Chemistry. 2009, 114(3), 939-946.

74. Lairon, D. Nutritional quality and safety of organic food. A review. Agronomy of Sustainable Development. 2010, 30, 33-41.

75. Wojciak, K.M. Meat and meat products quality from organic production system. Nauka Przyroda Technologie. 2012, 6(3), 1-9.

76. Nilzen, V.; Babol, J.; Dutta, P.C.; Lundeheim, N.; Enfält, A.C.; Lundström, K. Free range rearing of pigs with access to pasture grazing - effect on fatty acid composition and lipid oxidation products. Meat Science. 2001, 58(3), 267-275.

77. Hansen, L.L.; Claudi-Magnussen, C.; Jensen, S.K.; Andersen, H.J. Effect of organic pig production systems on performance and meat quality. Meat Science. 2006, 74(4), 605-615.

78. Grela, E.R.; Kowalczuk, E. Content of nutrients and fatty acid composition in meat and pork-butcher's meat from organicpig production. Zywnosc Nauka Technologia Jakosc. 2009, 16(4), 34-40. 
79. Semenikhina, T.V.; Bitueva, E.B. Comparative study of the chemical composition and biological value of meat of animals fed in pig farms and private farms. Bulletin of the Buryat State Agricultural Academy named after V.R. Filippova. 2012, 4(29), 88-93.

80. Knyazeva, A.S.; Vostrikova, N.L.; Ivankin, A.N.; Kulikovsky, A.V. Evaluation of the biological value of meat protein during storage of frozen meat. All About Meat. 2017, 2, 36-39.

81. Pietrzak-fiecko, R.; Modzelewska-kapituła, M. Fatty acid profile of polish meat products. Italian Journal of Food Science. 2014, 26(4), 363-369.

82. Gurinovich, G.V.; Malyutina, K.V.; Seregin, S.A.; Patrakova, I.S. Study of the effect of pork fatty acid composition on the fermentation process. Techniques and Technology of food production. 2020, 50(1), 32-43.

83. McNeill, S.H.; Elswyk, M.E.V. Red meat in global nutrition. Meat Science. 2012, 92(3), 166-173.

84. Ba, H.V.; Amna, T.; Hwang, I. Significant influence of particular unsaturated fatty acids and $\mathrm{pH}$ on the volatile compounds in meat-like model system. Meat Science. 2013, 94(4), 480-488.

85. Estevez, M.; Morcuende, D.; Ventanas, S.; Cava, R. Analysis of volatiles in meat from Iberian pigs and lean pigs after refrigeration and cooking by using SPME-GC-MS. Journal of Agricultural and Food Chemistry. 2003, 51(11), 3429-3435.

86. Hartman, A.D.; Costello, W.J.; Libal, G.W.; Walhlstrom, R.C. Effect of sunflower seeds on performance, carcass quality, fatty acids and acceptability of pork. Journal of Animal Science. 1985, 60(1), 212-219.

87. West, R.L.; Myer, O.L. Carcass and meat quality characteristics and backfat fatty acid composition of swine as affected by the consumption of peanuts remaining in the field after harvest. Journal of Animal Science. 1987, 65(2), 475-480.

88. Warnants, N.; Van Oeckel, M.J.; Boucque', C.V. Incorporation of dietary polyunsaturated fatty acids into pork fatty tissues. Journal of Animal Science. 1999, 77(9), 2478-2490.

89. Enser, M.; Richardson, R.I.; Wood, J.D.; Gill, B.P.; Sheard, P.R. Feeding linseed to increase the n-3 PUFA of pork: fatty acid composition of muscle, adipose tissue, liver and sausages. Meat Science. 2000, 55(2), 201-212.

90. Myer, R.O.; Johnson, D.D.; Knauft, D.A.; Gorbet, D.W.; Brendemuhl, J.H.; Walker, W.R. Effect of feeding high-oleic acid peanuts to growing-finishing swine on resulting carcass fatty acid profile and on carcass and meat quality characteristics. Journal of Animal Science. 1992, 70(12), 3734-3741.

91. Campo, M.M.; Nute, G.R.; Wood, J.D.; Elmore, S.J.; Mottram, D.S.; Enser, M. Modelling the effect of fatty acids in odour development of cooked meat in vitro: Part I-sensory perception. Meat Science. 2003, 63(3), 367-375.

92. Gjerlaug-Enger, E.; Haug, A.; Gaarder, M.; Ljøkjel, K.; Stenseth, R.S.; Sigfridson, K.; Berg, P. Pig feeds rich in rapeseed products and organic selenium increased omega-3 fatty acids and selenium in pork meat and backfat. Food Science E Nutrition. 2014, 3(2),120-128.

93. Pion, S.J.; van Heugten, E.; See, M.T.; Larick, D.K.; Pardue, S. Effects of vitamin C supplementation on plasma ascorbic acid and oxalate concentrations and meat quality in swine. Journal of Animal Sciences. 2004, 82(7), 2004-2012.

94. Rossi, R.; Pastorelli, G.; Cannata, S.; Tavaniello, S.; Maiorano, G.; Corino, C. Effect of long term dietarysupplementation with plant extract on carcasscharacteristics meat quality and oxidative stability inpork. Meat Science. 2013, 95(3), 542-548.

95. Hwang, Y.H.; Hur, S.J.; Park, G.B.; Joo, S.T. Effects of dietary glycine betaine on blood characteristics and pork quality. Journal of Muscle Foods. 2010, 21(1), 87-101. 
96. Zhong, J.-F.; Wu, W.-G.; Tastan, A.; Zhang, X.-Q.; Wang, B.; Tang, X.-P.; Fang, R.-J. Effects of an immune stimulant, inactivated Mycobacterium phlei, on the growth performance as well as meat quality of fattening pigs. Animal Science Journal. 2018, 89(4), 703-712.

97. Ma X.; Zheng, C.; Hu, Y.; Wang, L.; Yang, X.; \& Jiang, Z. Dietary l-arginine supplementation affects the skeletal longissimus muscle proteome in finishing pigs. Plos One. 2015, 10(1),e0117294.

98. Hulshof T. G., van der Poel, A. F. B., Hendriks W. H., \& Bikker P. Amino acid utilization and body composition of growing pigs fed processed soybean meal or rapeseed meal with or without amino acid supplementation. Animal, 2017, 11, 1125- 1135. https://doi.org/10.1017/S1751731116002548

99. Calvo L., Segura J., Toldrá F., Flores M., Rodríguez A. I., López-Bote C. J., \& Rey, A. I. Meat quality, free fatty acid concentration, and oxidative stability of pork from animals fed diets containing different sources of selenium. Food Science and Technology International, 2017, 23(8), 716-728. doi:10.1177/1082013217718964

100. Chen J., Tian M., Guan W., Wen T., Yang F., Chen F., Song, H. Increasing selenium supplementation to a moderately-reduced energy and protein diet improves antioxidant status and meat quality without affecting growth performance in finishing pigs. Journal of Trace Elements in Medicine and Biology, 2019. doi:10.1016/j.jtemb.2019.07.004

101. Godziszewska J., Guzek D., Głąbska D., Jóźwik A., Brodowska M., Głąbski K., Wierzbicka A. Nutrient oxidation in pork loin is influenced by feed supplementation and packing methods. Journal of Food Composition and Analysis, 2017, 56, 18-24. doi:10.1016/j.jfca.2016.11.009

102. Pogorzelska-Nowicka E., Godziszewska J., Horbańczuk J., Atanasov A., \& Wierzbicka, A. The Effect of PUFA-Rich Plant Oils and Bioactive Compounds Supplementation in Pig Diet on Color Parameters and Myoglobin Status in Long-Frozen Pork Meat. Molecules, 2018, 23(5), 1005. doi:10.3390/molecules23051005

103. Tan, B.; Yin, Y.; Liu, Z.; Li, X.; Xu, H.; Kong, X.; Wu, G. Dietary l-arginine supplementation increases muscle gain and reduces body fat mass in growing-finishing pigs. Amino Acids. 2009, 37(1), 169-175.

104. Negreeva, A.N.; Yurieva, E.V.; Khlupov, A.A.; Ushakova, I.Yu. Influence of unconventional feed on the amino acid composition of pork. Proceedings of the conference, Michurinsk State Agrarian University; Michurinsk, Russia, 2017, 59-63. 